\title{
Adapting European Legislation to the Maritime Labour Convention 2006 Regulations in Relation to the State Responsibilities of Both the Flag State and the Control of Ships by Port State Control
}

\author{
Sara Ruano Albertos, Arántzazu Vicente Palacio \\ Department of Labour Law and Social Security, Universitat Jaume I, Castellón, Spain \\ Email: ruanos@uji.es, Arantzazu.Vicente@uji.es
}

Received January $4^{\text {th }}$, 2013; revised February 22 $2^{\text {nd }}, 2013$; accepted March $8^{\text {th }}, 2013$

\begin{abstract}
Copyright (C) 2013 Sara Ruano Albertos, Arántzazu Vicente Palacio. This is an open access article distributed under the Creative Commons Attribution License, which permits unrestricted use, distribution, and reproduction in any medium, provided the original work is properly cited.
\end{abstract}

\begin{abstract}
The Maritime Labour Convention (MLC) 2006, which will come into force as of 20 August 2013, contemplates a new system to guarantee its regulations are being applied by including Port State Control with traditional Flag State control. The European Union has incorporated the MLC 2006 into its legislation through an agreement reached with its European social agents, as a Directive, in virtue of Article 115 of the Court of Justice of the European Commission. Thus fulfilment of the MLC 2006 has become compulsory for all EU Member States. However, it has not yet been ratified and, besides, it is subjected to certain community Port State and Flag State control mechanisms, which improve the optional character with which they are contemplated in international regulations. This work briefly explains not only the community acceptance process and its consequences, but also the effectiveness that the Port State control's system, established in the community area, has had in 2011. The control of labour and social security conditions will soon benefit from this effectiveness.
\end{abstract}

Keywords: Flag State; Governing Port State; Maritime Labour Conformity Statement; Maritime Labour Certificate Port State Control MOUs; Directive 2009/13/EC; Directive 2009/16/EC

\section{Introduction}

The Maritime Labour Convention 2006 (referred to as the MLC 2006 henceforth) adopted on 23 February 2006 by the International Labour Organization (ILO) during its 10th. Maritime Meeting with 314 votes in favour and no votes against, has proved a major achievement as it has established unified regulations in an attempt to guarantee decent living and working conditions for seafarers. The very nature of ship transport and the special conditions in which maritime labour takes place, to which this sector's economic circumstances have contributed, which have led to the constant efforts made in cutting costs and have doubtlessly had an effect on seafarers' working conditions (International Labour Organitation, 2001) required an instrument that unifyingly and globally responds to the requirements of a sector with a worldwide scope to guarantee decent working conditions for seafarers.

Already existing maritime conventions and recommendations have been reviewed and updated in this Convention, which have been adopted by the ILO since 1920. It should be noted that the ILO members which do not ratify the new MLC 2006 will be committed to former conventions which would have been ratified, although these instruments would become invalid in the light of new ratifications when the new Convention came into being; that is to say, twelve months after their ratification by 30 ILO members, whose fleets represent no less than 33\% of the deadweight tonnage of the world's fleet. The following two conditions have already been met: ratification by Russia and the Philippines - in August 2012-determined the fulfilment of the ratification requirement by at least 30 ILO member countries, plus the requirement referring to the countries ratifying it representing at least $33 \%$ of the gross tonnage of the world's merchant fleet for the year 2009; thus only the corresponding 12-month period having to pass would be necessary for it to come into force.

In any case, this Convention, considered the fourth pillar upon with the international regulate regime along with the SOLAS, the STCW and the MARPOL Convention, meets three relevant objectives: firstly, it establishes a series of principles and rights, as laid down in the Articles and Regulations; secondly, it confers Member States a considerable degree of flexibility as to the way they apply these principles and rights through the Code; thirdly, it ensures that the application and the control of the application of these principles and rights are adequately carried out.

The MLC 2006 establishes a series of regulations on: the minimum requirements to be able to work onboard a ship (Title 1); conditions of employment (Title 2); conditions of accommodation, recreation facilities, food and catering (Title 3); conditions to protect health (FOTINOPOULOU BASURKO, 2001) (Title 4). Although all these requirements and conditions are 
relevant, they will not be so important in practice if there is no suitable system available to control their application and fulfilment, such as the provisions set out in Title 5: The system to control the application of rules as a basic pillar of the effectiveness of the convention; hence, the importance of the Flag State inspecting and approving the working and living conditions of seafarers is stressed because the Flag State is responsible for verifying that the maritime labour requirements are applied, as laid down in the MLC 2006; and also hence the importance of the inspections conducted by the Port State Control given their aim to ensure that that laid down in the Convention is fulfilled.

\section{The Maritime Labour Convention 2006: The Inspection System by the Flag State and Control Inspections by the Port State Control}

It is the responsibility of the Flag State to verify that ships comply with MLC 2006 requirements, and it is in charge of issuing the Maritime Labour Certificate (Regulation A5.1.3) as far as meeting the requirements corresponding to the fourteen aspects relating to the working and living conditions of seafarers, as set out in Title 5, Annexe A5-I, is concerned. Yet not all ships must be compulsorily certified, but only those whose gross tonnage is equal or over 500 tons, which travel on international journeys, or those ships whose gross tonnage is equal to or over 500 tons which sail under the flag of a country and operate from one port, or between the ports, of another country. Therefore, this obligation does not apply to those ships whose gross tonnage is under 500 tons or to those which do not travel on international journeys and do not operate from one port, or between the ports, of another country. Yet even so, the Port State Control should verify the fulfilment of these requirements applicable to certified ships in any case, even when they have not been issued a Maritime Labour Certificate or a Maritime Labour Conformity Statement. A shipowner can voluntarily request that a ship is certified even though the certificate is not compulsory for that ship.

The Maritime Labour Certificate is complemented with the Maritime Labour Conformity Statement, which comprises two parts: Part I, issued by the Port State Control and refers to the national legislation to which an agreed list of fourteen aspects is applied that must be the object of certification (RUANO ALBERTOS, 2009); Part II establishes the shipowner's or operator's plan to guarantee that the regulations are respected onboard the ship among the various inspections made.

Furthermore, it should be taken into account that the documents which the Port State Control issues can also be issued by an organisation that has been recognised by and is authorised to act on its behalf. Indeed, Regulation 5.1.1, Paragraph 3, of the MLC 2006 allows public institutions and other recognised competent, independent organisations to be authorised by a Port State Control to conduct inspections or to issue certificates, or both, on its behalf. Regulation A5.1.2 specifies the requirements that the Port State Controls which wishes to name public institutions or other organisations have to apply in order to conduct inspections as set out in the MLC 2006; they must provide the International Labour Organization (ILO) with an up-to-date list of all the authorisations granted to recognized organisations.

For the purpose of helping fulfil the obligations laid down in the Port State Control in accordance with that set out in the
MLC 2006, the ILO has published a series of Guidelines (International Labour Organization, 2009), which stress the importance of Flag State Control (or its competent authority) in preparing a series of documents, provided, evidently, that they do not already exist. Hence in relation to the ship's certification, a national version of the form known as the Maritime Labour Certificate must be prepared and the two parts of the Maritime Labour Conformity Statement must be written. Moreover, the Maritime Labour Convention foresees other standard format documents: that which describes the working organisation onboard the ship; a medical certificate and a standard onboard medical report form. Furthermore, a system that registers inspection reports should also be set up.

Among the Port State Control's responsibilities, the following should also be stressed given their importance: receiving and investigating complaints, and adopting suitable control measures; procedures to receive and respond to complains must be set up, with confidentiality guaranteed. Consequently, prior to issuing or countersigning a certificate or authorising a ship to sail, the Port State Control inspector should have confirmation that all the shortcomings identified during the inspection have been rectified or that the shipowner has provided a plan of action to correct them, which must be approved by the inspector.

Port State Control civil servants must also help ensure decent working conditions for seafarers, in such a way that all the ships to which the MLC 2006 applies, irrespectively of their size, and which make ports of call in foreign ports of Member States that have ratified this Convention, may be the object of inspection (International Labour Organitation, 2009). In fact, the Member States that ratify the MLC 2006 are responsible for conducting control inspections by the Port State in the foreign ships found in their ports through either their own initiative or a complaint. Moreover, an inspection in a foreign port is applicable even for ships sailing under the flag of a country that has not ratified the MLC 2006 because the Convention itself obliges Member States that have ratified it to not favourably treat ships sailing under the flag of those Member States that have not ratified it (principle of no more favourable treatment). This means they may be subjected to a more detailed inspection because the ships are not certified.

In short, the intention here is to determine whether the inspected ship complies with that set out in the MLC 2006 on the living and working conditions of seafarers onboard the ship in question. In principle, these inspections will refer to the fourteen requirements relating to the onboard living and working conditions, whose certification should have already been issued by the Flag States that have ratified the MLC 2006, which basically obliges them to certify. In such cases, the Maritime Labour Certificate and the Maritime Labour Conformity Statement must be the starting point of the inspection as they are considered sufficient proof that requirements are met, unless there is proof otherwise. If the ship does not sail under the flag of a Member State which has ratified the Convention, it could be subject to a more detailed inspection.

Although the MLC 2006 does not specify inspections in compulsory terms, which are merely optional, it expects the Port State inspection and control system to be efficient in checking whether the Convention's aims are being met. It even expects that the reports to be presented by virtue of Art. 22 of the ILO Constitution include information about this system, and even the method to evaluate its efficacy. Although it does not infer its compulsoriness, it expects genuine willingness for the 
control system to be fulfilled. The fact that it is not compulsory can prove a serious impediment for its effectiveness, unless other sources of regulations exist that derive from other applications establishing this compulsoriness; this occurs in, for example, the European Union, as indicated below.

Along with the aforementioned obligations, Port State Control civil servants are in charge of the proceedings and the investigation of the complaints presented by seafarers on board the ships visiting their ports.

All in all, any identified shortcomings should be pointed out to the ship's captain and a deadline date for their rectification shall be indicated. If these shortcomings are considered important, they shall be made known to the seafarers' and shipowners' associations in the Port State (VICENTE PALACIO, 2009) in which the inspection was done. The intention here is to avoid that ships are improperly immobolised or delayed. This allows the ship to sail provided that the shortcomings have been rectified, unless the onboard conditions clearly prove to be a risk for seafarers' health and safety; or should the detected shortcoming or shortcomings in conformity prove to be a serious or recurrent offence of that laid down in the Convention. Recurrent offences could be a sufficient reason to immobilise a ship.

\section{European Union Regulations on Flag State Responsibilities and on the Port State's Control of Ships}

The European Union has not ignored (EUROPEAN PARLIAMENT, 2010) the need for a unified and global set of regulations that ensure decent living and working conditions for seafarers, and bearing in mind that these minimum unified and global regulations not only improve the living and working conditions of seafarers, but also allow fairer conditions in the maritime sector (VICENTE PALACIO, 2009).

In line with this, after approving the MLC 2006, the European Union (EUROPEAN ECONOMIC AND SOCIAL COMMITTEE, 2006) became aware of the convenience of immediate ratification by its Member States, which led it to adopt Council Decision 2007/431/EC, of 7 June, with which Member States are authorised to ratify, in the interest of the European Community, the aforementioned MLC 2006. It also indicates that this was to be before 31 December, 2010, if possible (DO L.161, of 22 June, 2007)

Indeed in 2007, the European Commission (EUROPEAN COMMISION, 2007) had already proposed a comprehensive maritime policy to help improve Europe's capacity to face challenges of a globalisation and competitiveness kind by considering combined efforts to be made by all the parties involved in the maritime sector necessary in order to improve policies relating to the personnel and working conditions by establishing an efficient regulatory framework that would consider the international context. Thus the Commission fully backed the social dialogue that was underway on incorporating the MLC 2006 into Community Law, which resulted in the Agreement between the European Community Shipowners Associations (ECSA) and the European Transport Workers Federation (ETWF) on the MLC 2006 being adopted. By following a Community Law procedure to convert the agreements resulting from community social dialogue into community regulations (Treaty Art. 115), Council Directive 2009/13/EC, of 16 February 2009, was adopted. It incorporates practically all minimum requiriments, working conditions, provisions on accommoda- tion, installations, and provisions on board complaints procedures the 2006 MLC provisions into Community Directive 2009/13/EC, which shall come into force simultaneously when the MLC 2006 does - that is, on 20 August 2013 - and it shall allow a 12-month period after it comes into force for Member States to implement their contents to Domestic Law. The only matters that it does not cover are those relating to salaries, social security (because the latter is beyond the European Union's competence, except for coordination matters) and establishing control mechanisms for both Flag States and Port States, which remain beyond the competence of social agents, these being the true developers of community law.

The regulatory role that the European Union plays in maritime transport matters dates well back in the past and is based on seeking mechanisms to ensure the effectiveness of the International Maritime Organization's (IMO) international regulations in order to reinforce international regulations within the ever more effective community code. We should bear in mind that not even regional Agreements on Port State control-endorsed by the proposal of IMO itself (Resolution A.682 (17)) can ensure a level of efficacy for fulfilling these international regulations because its foresights do not establish legal obligetions for members. Otherwise, they are generally limited to the IMO's own Agreements, and then only in very isolated cases (Paris-MOU and Tokyo-MOU), and are extremely limited to some ILO Agreement, specifically Convention no. 147 (1976) on minimum regulations on social security matters. Indeed, these regional Agreements do not specify any rules or procedures, be it in various ways, to ensure that norms on navigation security and safety are actually fulfilled by State Signatories, and that they are generally dedicated to overall or individual, yet poorly ambitious, inspection commitments; for instance, Viña del Mar-MOU and the Mediterranean-MOU, whose individual inspection objective establishes $20 \%$ of the ships reaching State Signatories' ports for each Member State. The Tokyo-MOU is considerably more ambitious as it sets an overall objective for all the State Signatories in the Agreement of $80 \%$ of the ships reaching ports. The Committee created by the Tokyo-MOU has established inspection quotas for all members. However, doubtlessly the most ambitious Agreement is the Paris-MOU, which resulted from the tight connections between the Paris-MOU expectations and community regulations, which we will look at later. These community expectations are genuine obligations for Member States, without them being also conditioned to ratifying international Conventions whose compliance is stated. All in all, community intervention in relation to the obligations of both Flag States and Port States address certain limited socio-occupational questions, as only set out specifically in the ILO Convention no. 147 on minimum regulations for social security matters (1976) and in its 1996 Protocol.

\section{Flag State Control: The New Directive Proposal for the Control of Applying the Obligations Deriving from Directive 2009/13/EC}

Indeed, in relation to the Flag State's obligations, the European Union adopted Directive 2009/21/EC of the European Parliament and Council, of 23 April 2009, on the fulfilment of Flag State's obligations, was adopted (DO L 131 of 28 May 2009) for two purposes: on the one hand, the intention was to guarantee that Member States efficiently and coherently com- 
plied with their obligations as the Flag States that they are; on the other hand, the aim was to improve maritime safety and to avoid pollution from ships sailing under Flag Member States. In short, the objective was none other than Member States fulfilling their obligations as Flag States in accordance with IMO conventions. Nevertheless, this Directive did not respond to the specific responsibilities that the Flag Member State must bear in terms of controlling compliance with that laid down by Directive 2009/13/EC which, as indicated, includes certain MLC 2006 regulations; thus it has been necessary to update the regulations on Flag State Control on the verification and control of the requirements set out by the MLC 2006. There is no doubt whatsoever that the Flag State is obliged to ensure that its ships comply with international regulations and, in this case, that the parts of the MLC 2006, which is incorporated into community regulations by means of Directive 2009/13/EC, are met. To this end, a Directive is proposed-Proposal of the European Parliament and Council Directive COM (2012) 134, FINAL, which complements Directive 2009/21/EC, and which ensures that EU Flag States shoulder their responsibilities as far as applying and observing the cited Directive 2009/13/EC are concerned. The EU has decided to make arrangements to control the Flag State responsibilities deriving from Directive 2009/13/CE autonomously to controlling those aspects relating to the technical aspects of navigation safety, as set out in Directive 2009/21/EC, which has no list of obligations that the Flag State must comply to, but refers to all IMO procedures. This autonomous rule has two major consequences:

1) Firstly, the proposed Directive has not included the certification system set out in the MLC 2006 in the Community Law domain for the purpose expressly set out, that of avoiding a new tier of regulations for Member States in order to, therefore, maintain the certification system in the International Law domain. The scope of this proposal is much more limited: it only establishes regulations so that Member States fulfil their obligations as Flag States insofar as supervising that Directive 2009/13/EC is fulfilled. These obligations are specified in the demand of the obligation that guarantees the establishment of suitable supervision controls and mechanisms, and performing effective and adequate inspections to ensure that onboard working conditions under the flag of a country comply with the requirements set out in Directive 2009/13/EC. Therefore, the Directive proposal does not impose the certification obligation set out in the MLC 2006: despite effective and suitable inspections having to be conducted, they do not necessarily finish in issuing an MLC 2006 certificate.

2) Secondly, there is no exact identity available in the area where the Directive Proposal and the MLC 2006 under study actually apply. Therefore, the obligations deriving from Directive 2009/13/EC — and therefore, control—apply to all the public and private ships that normally undertake commercial activities, without being restricted to those ships to which the certification obligation set out in the MLC 2006 applies.

\section{Port State Control: The New Certificates Set out in the MLC 2006 Are Included in Directive 2009/16/EC. Analysing the Effectiveness of the Control Exerted by the Port State as Set out in Directive 2009/16/EC in the Light of the 2011 Statistics}

If, as indicated, the Flag State assumes a relevant role in controlling that the MLC 2006 regulations are indeed applied, then it is worth remembering the important task, involved in their fulfillment, carried out by the governing Port State.

In the community setting, Directive 2009/16/EC, on the governing Port State's control of ships, reinforces the fulfilment of international legislation and European Union legislation on maritime safety, maritime protection, environmental marine protection, and the onboard working and living conditions of any Flag State's ships; it also sets out common criteria for the governing Port State to inspect ships. In fact, the Paris-MOU came into force as of 1 July 1982 to facilitate the inspections of those ships sailing under foreign flags by governing Port States in order to verify that they meet the regulations included in the various international instruments by setting the frequency of these inspections in terms of their risk profile, and by submitting those ships at greater risk to more detailed inspections Community regulations-in agreement with that set out in the Paris-MOU, but improving it by converting its objectives into obligations for State Members-establish the aforementioned ambitious inspection objective: firstly, when inspecting all ships assigned a Priority I index, as set out in Letter a) of Art. 12 of the Directive; secondly, an annual fee for all the ship inspections assigned Priority Indices I and II made must be paid, as set out in Art. 12, Letters a) and b). This is at least the equivalent of the corresponding fee of the total number of inspections made each year in the Community and in the Paris-MOU region. The inspection quota is attributed to Member States and is based on the ratio between the number of ships docking in State Members' ports and each Member State of the Community and the Paris-MOU region.

The MLC 2006 is to imminently come into force, particularly Directive 2009/13/EC, which includes most MLC 2006 contents, and which will convert it into a compulsory measure for all Member States, irrespectively of them having ratified, or not, the MLC 2006. To this end, Directive 2009/16/EC, on Port State control, had to be updated for it to be in keeping with the new documents and agreements that the MLC 2006 incorporates. In line with this, a Directive proposal-COM (2012), 129 FINAL-is being processed which specifically states, in relation to the documents created for the MLC 2006, that inspectors should verify by their inspections that ships have the Maritime Labour Certificate and the Maritime Labour Conformity Statement. Likewise, the in- spections domain is extended, and a procedure for complaints has been set up, which has to be followed for any complaint relating to any matter covered by the MLC 2006.

Along this line, what the Directive Proposal intends is to not change the current claims system already set up for Directive 2009/16/EC, rather it is complemented by a suitable complaints procedure for MLC 2006-relatd complaint. In order to ensure uniform conditions for this procedure to be applied, the Commission will also be responsible for the execution competences that relate with not only setting up a harmonised electronic format to present and follow-up claims by State Port authorities, but also with a procedure to notify the follow-up measures taken by Member States.

This is doubtlessly a major advance for the effectiveness of the MLC 2006 in the community domain. Firstly because the material or fundamental obligations foreseen in the MLC 2006 will be compulsory for all Member States when it comes into force, irrespectively of them having ratified the MLC 2006 or not, as regulations are now included in community heritage, whose fulfillment will become compulsory for all Member 
States. Secondly, and fundamentally, because the control accomplished from complying these rules also applies to the community domain and with the same range of compulsoriness that derives from any community regulation-a Directive in this case and in specific Port State control mechanisms terms. It also implies a substantial improvement of its effectiveness given that high levels of effectiveness derive from Member States having to fulfil obligations in the inspection matters set out in Directive 2009/16/EC. Indeed, available data (COMMISION, 2012) reveal that, in general, the inspection commitments deriving from Directive 2009/16/EC have been fulfilled for the year 2011 in terms of both priority I ships [Art. 5.1. a) relating to the specific regulations of Art. 6] and the inspection quotas set out in Art. 5.1. b), with very few exceptions. This same level of efficacy is expected to continue in the future when Port State control also accomplishes the working conditions set out in the MLC 2006.

Indeed, this Report indicates, in relation to applying Art. 6.1 in Directive 2009/16/EC in 2011, that twelve (of the 22) EU Member States-Belgium, Bulgaria, Germany, Cyprus, Malta, The Netherlands, Portugal, Romania, Slovenia, Finland, Sweden and the United Kingdom, also aplicable to Croatia, Iceland, Norway and Russia found themselves in this situation. As shown in the table (Figure 1), which indicates the commitment and number of inspections made by Member States to which Article 6 applies, the levels are highly satisfactory: for Priority I ships, the overall percentage reached is $67.59 \%$, while this percentage for the inspections made of Priority II ships is $94.70 \%$ of the global inspection quota.

For those ships included in the special system set out in Art. 7.2 (underload status), the Figure below (Figure 2) shows the commitment and number of inspections made by these "underloaded" Member States, from which it is deduced that these Member States made Priority I inspections, as expected given the commitment, and that almost all of them made the required number of priority II inspections.

Finally for overloaded ships, the higher level of failure to fulfil the Priority I ships inspection commitment is observed (Figure 3).

Nonetheless, the evaluation of the above data must be related with the high levels of demand deriving from community regu-

\begin{tabular}{|c|c|c|c|c|c|c|}
\hline & $\begin{array}{c}2011 \\
\text { Commitment }\end{array}$ & Calls PI & $\begin{array}{c}\text { PI } \\
\text { inspected }\end{array}$ & Calls PII & $\begin{array}{c}\text { PII } \\
\text { inspected }\end{array}$ & $\begin{array}{c}\text { PI+PII } \\
\text { inspected }\end{array}$ \\
\hline Belgium & 1168 & 521 & 475 & 1082 & 496 & 971 \\
\hline Bulgaria & 313 & 290 & 273 & 310 & 255 & 528 \\
\hline Cyprus & 223 & 207 & 52 & 232 & 73 & 125 \\
\hline Finland & 324 & 94 & 78 & 527 & 238 & 316 \\
\hline Germany & 1177 & 559 & 517 & 964 & 887 & 1404 \\
\hline Iceland & 58 & 22 & 19 & 55 & 43 & 62 \\
\hline Malta & 333 & 194 & 185 & 303 & 45 & 230 \\
\hline Netherlands & 1527 & 1456 & 1026 & 1964 & 557 & 1583 \\
\hline Norway & 570 & 374 & 234 & 811 & 360 & 594 \\
\hline Portugal & 574 & 263 & 239 & 397 & 206 & 445 \\
\hline Romania & 430 & 374 & 239 & 467 & 437 & 776 \\
\hline Slovenia & 163 & 98 & 97 & 149 & 143 & 240 \\
\hline Sweden & 608 & 166 & 130 & 650 & 226 & 356 \\
\hline $\begin{array}{c}\text { United } \\
\text { Kingdom }\end{array}$ & 2046 & 1634 & 765 & 1773 & 776 & 1541 \\
\hline Totals & 9514 & 6252 & 4429 & 9684 & 4742 & 9171 \\
\hline
\end{tabular}

Figure 1.

Commitment and number of inspection made by Member States (art. 6). Source: Commision to the European Parliament and Council (2012).

\begin{tabular}{|c|c|c|c|c|c|c|}
\hline & $\begin{array}{c}2011 \\
\text { Commitment }\end{array}$ & Calls PI & $\begin{array}{c}\text { PI } \\
\text { inspected }\end{array}$ & Calls PII & $\begin{array}{c}\text { PII } \\
\text { inspected }\end{array}$ & $\begin{array}{c}\text { PI+PII } \\
\text { inspected }\end{array}$ \\
\cline { 3 - 6 } Denmark & 588 & 196 & 173 & 320 & 209 & \multirow{2}{*}{382} \\
\hline Estonia & 328 & 68 & 65 & 134 & 120 & 185 \\
\cline { 3 - 6 } Latvia & 430 & 71 & 66 & 187 & 180 & 246 \\
\hline Lithuania & 347 & 66 & 62 & 125 & 120 & 182 \\
\cline { 3 - 6 } Poland & 531 & 156 & 139 & 324 & 293 & 432 \\
\hline Totals & 2224 & 557 & 505 & 1090 & 713 & 1427 \\
\hline
\end{tabular}

\section{Figure 2.}

Commitment and number of inspections made by "underloaded" Member States. Source: Commision to the European Parliament and Council (2012).

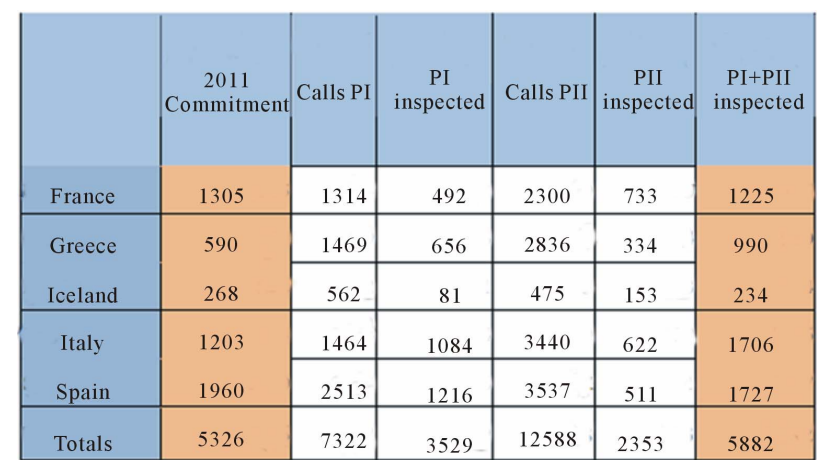

\section{Figure 3.}

Commitment and number of inspections made by "overloaded" Member States. Source: Commision to the European Parliament and Council (2012).

lations, these being much higher than those expected of other regional Agreements. By way of example, and not based on the data available of the number of stops that ships made in the ports included in the region where the Viña del Mar-MOU applies, 8584 inspections were made in 2010 (ACUERDO LATINO, 2010). This number is considerably less than the 16,425 inspections made in the Paris-MOU region, despite the broad geographic area to which this Agreement applies (Argentina, Bolivia, Brazil, Colombia, Chile, Cuba, Ecuador, Honduras, Mexico, Panama, Peru, Uruguay and Venezuela). Likewise in the Tokyo-MOU region (PORT STATE CONTROL IN THE ASIA-PACIFIC REGION, 2011) the inspection rate is lower than that of Europe, $68 \%$ (23,268 inspections for 28,627 dockings) (it comprises the following State Signatories: Australia, Canada, Chile, China, Fiji, Hong Kong (China)), Indonesia, Japan, Republic of Korea, Malaysia, New Zealand, Papua New Guinea, the Philippines, the Russian Federation, Singapore, Solomon Islands, Thailand, Vanuatu and Vietnam. For the Port State control carried out in the United States, the inspection rates are also considerably lower, barely reaching $24.08 \%$ with 19,038 inspections for 79,031 port dockings (UNITED STATES COAST GUARD, 2011). At any rate, it is necessary to insist that the current community system since Directive 2009/16/EC — and the Paris-MOU domain, present added value for not only some greater quantitative inspection commitments than those deriving from any of the cited regional Agreements, but also given its distinct nature as it uses a mixed criterion to 
select inspectionable ships, unlike the cited agreements which, at best, although establish, and indeed approach good, ambitious inspection levels, their selection criteria are merely quantitative.

\section{Conclusion}

The MLC 2006 lays down unified regulations to accomplish better living and working conditions of seafarers. Establishing these minimum regulations, and the impact of them not being met will contribute to fairer maritime sector competences. Doubtlessly, one of the most relevant aspects of the Convention lies in establishing suitable mechanisms to control that regulations are being effectively applied. Controlling that Flag Member States are applying regulations, are conducting the corresponding ships inspections and are certifying the fulfilment of that laid down in the Convention, is a major step towards effectively improving working conditions. In parallel, the controls carried out by governing Port States are absolutely necessary to guarantee that these working conditions apply. All in all, the lack of compulsoriness in governing Port States establishing inspection quotas may determine a lower level of efficacy than that desired. Thus it would be desirable that the various MOUs for Port State control also integrate the new documents that the MLC 2006 is to establish among the expected certificates. In line with this, the European Union is currently in a very advanced stage, and is doubtlessly the maritime region that has best developed in such matters thanks to: the incorporation of community heritage, with the characteristic level of compulsoriness deriving from its regulations; practically all the MLC 2006 content; the mechanisms of control by the Flag State and, above all, by the Port State. In this way, practically the whole MLC 2006 will oblige Community States as Flag States, even though they have not ratified it, to have accepted the certification obligation, which is doubtlessly a lost opportunity to have achieved the highest possible level of regulatory effectiveness in a matter that is a priority objective for the EU. Moreover, the system of Port State control, established by community regulations, will also extend the control of the working conditions foreseen in the MLC 2006 by demanding those ships docking in its ports to comply with the certification system deriving from the MLC 2006. As it is a system that makes the fulfilment of high quotas compulsory, unlike the rest of the indicated administrative agreements, it will have a bearing on better MLC 2006 implementation in this geographical area by definitively improving shipping working conditions on a worldwide scale, and by re-establishing equitable competence conditions.

\section{Acknowledgements}

This work was conducted under the research project "Transformations of Labour and Social Security to the European and global crises" funded by Bancaja (2012-14) and “The international maritime safety regulations and their impact on the protection of labour rights of seafarers" funded by Ministry of Science and Innovation (National Plan I+D+i (2008-11)).

\section{REFERENCES}

Acuerdo Latino (2010). Annual Statistics Report.

http://www.acuerdolatino.int.ar/

Commission (2007). Communication from the Commission to the European Parliament to the Council, to the European Economic and Social Committee and to the Region's Commission. A comprehendsive maritime policy for the European Union, Brussels, 10 October, 2007, COM (2007) 575, FINAL.

Commission to the European Parliament and Council (2012). Evaluation report of the application and repercussion of the measures adopted in accordance with Directive 2009/16/EC on governing Port State control of ships, Brussels, 16 November 2012, COM (2012) 660 final.

European Economic and Social Committee (2006). Decision on the third package of maritime safety, DOC 318 of 23 December, 2006.

European Parliament (2010). On Strategic Objectives and Recommendations for the EU Maritime Transport Policy until 2018, 30 March, 2010 (2009/2095(INI)).

Fotinopoulou Basurko, O. (2001). Detecting that a seafaring woman is pregnant during a medical examination prior to embarking. Aranzadi Social, 21, 82.

International Labour Organization (2001). The impact of the changes made to the shipping industry structure on the living and working conditions of seafarers (ILO, JMC/29/2001/3).

International Labour Organization (2009). Guidelines for Port State inspections according to the Maritime Labour Convention. Geneva: ILO.

Port State Control in Asia-pacific Region (2011), Annual Report of Port State Control in the Asia-Pacific region. http://www.tokyo-mou.org/organization/

Ruano Albertos, S. (2009). The Maritime Labour Convention. Requirements to work onboard ships: Minimum age, medical certificate, training and qualifications. Revista del Ministerio de Trabajo e Inmigración, 82, 125-158.

United States Coast Guard (2011). Port State Control in the United States. Annual Report, Department of Homeland Security. https://homeport.uscg.mil/mycg/portal/ep/browse.do?channelId=-183 71\&channelPage=\%2Fep\%2Fchannel\%2Fdefault.jsp\&pageTypeId= 13489\&BV_SessionID=@@@@1602917500.1357142085@@@@ \&BV_EngineID=ccceadfijmljlmicfngcfkmdfhfdfgn.0

Vicente Palacio, A. (2009). The ILO Maritime Labour Convention (MLC, 2006) is closer to coming into force. The latest actions taken by Spain and the European Union to favour the occupational protection of seafarers. Revista General de Derecho del Trabajo y de la Seguridad Social (IUSTEL), 20, 10-39.

Vicente Palacio, A. (2009). Control by the Port State of the living and working conditions onboard the ships which employ community ports or installations located on the waters that come under the jurisidiction of the Member States in community regulations. In Cuestiones actuales sobre Derecho Social Comunitario, Ediciones Laborum, Murcia. 